\title{
BALANCED SCORECARD (BSC) : REKAYASA PADA ENTITAS RUMAH SAKIT
}

\author{
Lukman Effendy \\ Fakultas Ekonomi dan Bisnis Universitas Mataram \\ lukman.effendy@unram.ac.id \\ Baiq Anggun Hilendria L.
}

Fakultas Ekonomi dan Bisnis Universitas Mataram

hilendria@unram.ac.id

Isnawati

Fakultas Ekonomi dan Bisnis Universitas Mataram

isnawati.isna@unram.ac.id

Diterima : 21 April 2020

Direview : 19 Mei 2020

Diterima : 10 Juni 2020

\begin{abstract}
Hospital Performance cannot be measured in the short term with the traditional financial management model. The Balanced Scorecard (BSC) is a new framework for integrating measures obtained from strategies. While maintaining its financial measures before, the BSC introduces additional items that include consumers, internal business processes, and learning and growth perspectives. It is more than just a measurement system. There are two (2) main objectives of this study, including: a) to find out the hospital performance evaluation model with the Balanced Scorecard approach; b) to find out the weight scale and score for evaluating Hospital performance using the BSC approach. This goal will be achieved by mapping the results of previous studies that have tried to measure hospital performance with the BSC approach to design a general measurement model that can be used as a reference in hospital entities. Then, this study also tried to formulate specific weight and score for hospital entities for each perspective assessed by the BSC approach. The conclusions in this study are: the minimum formulation of hospital performance appraisal, namely: a) Financial perspective can be use the economic ratio, efficiency ratio, ratio of equity and current of hospital finance; b) consumen (Patient) perspective is more appropriate to be assessed by looking at the ratio of patient satisfaction with hospital services; c) Internal Business Perspective is more appropriate to be assessed by looking at the
\end{abstract}


Effendy, Hilendria \& Isnawati: Balanced Scrocard (BSC)...

quality of Hospital services from the ALOS, BOR, TOI, BTO, GDR and Hospital NDR sides; d) Growth and Learning Perspectives can be seen by assessing the ratio of employee satisfaction, retention rates and motivation levels held by hospital employees. The criteria for scoring for each hospital performance appraisal perspective with the BSC approach varies which can be based on the Minister of Health's rules, theoretical concepts of the components being assessed and can also use the hospital's achievement targets.

\section{Keywords: Balanced Scorecard (BSC); Performance; Score;}

\section{Abstrak}

Kesuksesan Rumah Sakit tidak dapat dimotivasi atau diukur dalam jangka pendek dengan model manajemen keuangan tradisional saja. Balanced Scorecard merupakan kerangka kerja baru untuk mengintegrasikan ukuran yang diperoleh dari strategi. Dengan tetap mempertahankan ukuran keuangan sebelumnya, Balanced Scorecard memperkenalkan item tambahan yang meliputi konsumen, proses bisnis internal, dan perspektif pembelajaran dan pertumbuhan. Balanced Scorecard lebih dari sekedar sistem pengukuran. Terdapat dua (2) tujuan utama dari penelitian ini, diantaranya : a) untuk mengetahui model penilaian kinerja Rumah Sakit dengan pendekatan Balanced Scorecard.; b) untuk mengetahui besaran bobot dan skor untuk penilaian kinerja Rumah Sakit dengan pendekatan Balanced Scorecard. Tujuan tersebut akan dicapai dengan cara memetakan hasil-hasil penelitian sebelumnya yang telah mencoba mengukur kinerja Rumah sakit dengan pendekatan Balanced Scorecard (BSC) guna mendesain model pengukuran yang umum dan bisa digunakan sebagai acuan di entitas Rumah Sakit. Selain itu juga penelitian ini juga mencoba merumuskan besaran bobot dan skor khusus untuk entitas Rumah sakit untuk setiap perspektif yang dinilai dengan pendekatan BSC. Kesimpulan dalam penelitian ini antara lain: rumusan minimal penilaian kinerja Rumah Sakit yaitu: a) Perspektif Keuangan minimal menilai tingkat ekonomis, efisiensi, tingkat efektifitas dan tingkat lancar dari keuangan Rumah Sakit; b) Perspektif Pasien lebih pas dinilai dengan cara melihat tingkat kepuasan pasien terhadap pelayanan Rumah Sakit; c) Perspektif Bisnis Internal lebih pas dinilai dengan cara melihat mutu layanan Rumah Sakit dari sisi ALOS, BOR, TOI, BTO, GDR dan NDR Rumah Sakit; d) Perspektif Pertumbuhan dan Pembelajaran dapat dilihat dengan cara menilai tingkat kepuasan karyawan, tingkat retensi dan tingkat motivasi yang dimiliki oleh karyawan Rumah Sakit. Kriteri pemberian skor untuk masing-masing perspektif penilaian kinerja Rumah Sakit dengan pendekatan BSC bervariasi yang dapat didasarkan pada aturan Menteri Kesehatan, konsep teori dari komponen yang dinilai serta dapat juga menggunakan target capaian dari Rumah Sakit.

Kata Kunci : Balanced Scorecard (BSC); Kinerja; Skor. 


\section{PENDAHULUAN}

Saat ini masih banyak Rumah Sakit yang mengukur kinerjanya hanya berdasarkan pada tolak ukur keuangannya saja. Padahal dalam menghadapi lingkungan bisnis yang semakin berkembang saat ini, maka pengukuran kinerja dengan lebih menfokuskan sector keuangan saja sudah tidak lagi memadai karena memnpunyai banyak kelemahan, antara lain seperti: Pemakaian kinerja keuangan sebagai satu-satunya penentu kinerja Rumah Sakit bisa mendorong kepala Rumah Sakit untuk mengambil tindakan jangka pendek dengan mengorbankan kepentingan jangka panjang. Misalnya, untuk menaikkan profit atau ROI (Return on investment), seorang kepala Rumah Sakit bisa saja mengurangi anggaran untuk pengembangan atau pelatihan bagi karyawan, termasuk investasi dalam sistem teknologi untuk kepentingan Rumah Sakit dimasa depan. Dalam jangka pendek kinerja keuangan meningkat, namun dalam jangka panjang akan menurun.

Diabaikannya aspek pengukuran non-finansial pada umumnya, baik dari sumber internal maupun eksternal akan memberikan suatu pandangan yang keliru bagi kepala Rumah Sakit mengenai Rumah Sakit di masa sekarang terlebih lagi di masa datang. Kinerja Keuangan hanya bertumpu pada kinerja masa lalu dan kurang mampu sepenuhnya untuk menuntun Rumah Sakit kearah tujuan Rumah Sakit yang lebih baik. Setiap Rumah Sakit, harus menginvestasikan dan mengelola aset intelektual mereka. Hal ini disebabkan karena aset intelektual memampukan Rumah Sakit untuk berbagai hala seperti :a) Membangun hubungan baik dengan konsumen yang akan memelihara kesetiaan dari konsumen yang ada dan memungkinkan segmen konsumen dan area pasar yang baru dapat dilayani dengan efektif dan efisian; b) Memperkenalkan jasa inovatif yang diinginkan oleh target segmen konsumen; c) Memproduksi jasa yang berkualitas tinggi pada tingkat biaya yang rendah dan dengan waktu rawat yang singkat; d) Mengerahkan 
Effendy, Hilendria \& Isnawati: Balanced Scrocard (BSC)...

kemampuan dan motivasi karyawan untuk melakukan peningkatan secara terus menerus dalam pelayanan kapabilitas proses, kualitas, dan waktu respon, dan lain sebagainya.

Kesuksesan Rumah Sakit tidak dapat dimotivasi atau diukur dalam jangka pendek dengan model manajemen keuangan tradisional saja. Balanced Scorecard merupakan kerangka kerja baru untuk mengintegrasikan ukuran yang diperoleh dari strategi. Dengan tetap mempertahankan ukuran keuangan sebelumnya, Balanced Scorecard memperkenalkan item tambahan yang meliputi konsumen, proses bisnis internal, dan perspektif pembelajaran dan pertumbuhan. Balanced Scorecard lebih dari sekedar sistem pengukuran.

Rumah Sakit dapat menggunakan Balanced Scorecard sebagai dasar untuk mengatur kerangka kerja untuk proses manajemen mereka. Rumah Sakit dapat membangun Balanced Scorecard mula-mula dengan tujuan yang terbatas, misalnya untuk mendapatkan klarifikasi dan fokus terhadap strategic pada Rumah Sakit, lalu mengkomunikasi strategik tersebut kepada seluruh anggota Rumah Sakit. Dengan kata lain, Balanced scorecard mendidik manajemen dan organisasi pada umumnya untuk memandang Rumah Sakit dari empat perspektif yaitu keuangan, pelanggan, proses bisnis internal, dan perspektif pembelajaran dan pertumbuhan yang menghubungkan pengendalian operasional jangka pendek ke dalam visi dan strategi bisnis jangka panjang.

Seperti yang telah disebutkan diatas, Balanced Scorecard mengklarifikasi pengukuran kinerja ke dalam 4 perspektif yaitu, keuangan, pelanggan, proses bisnis internal, dan pembelajaran dan pertumbuhan. Keempat perspektif ini menawarkan suatu keseimbangan antara tujuan jangka pendek dan tujuan jangka panjang, yaitu hasil yang diinginkan, pemicu kinerja, dan tolak ukur kinerja. Dan sudah banyak penelitian yang mencoba mengukur kinerja sebuah Rumah Sakit dengan menggunakan pendekatan BSCtersebut, seperti Sibarani dan Zahara (2012); Rikmasari et al., (2014); 
Nuraini (2018); Ariantari (2019). Namun sampai dengan saat ini belum terdapat model pengukur dan bobot serta skor yang umumnya bisa digunnakan oleh Rumah Sakit. Sehingga pengukuran kinerja sebuah oraganisasi dengan pendekatan BSC khususnya entitas Sumah Sakit memiliki model perhitungan dan skor yang beragam. Oleh karena itu berdasarkan hasil perhitungan kinerja setiap Rumah Sakit di Indonesia dengan BSC yang dilakukan oleh peneliti-peneliti sebelumnya, maka penelitian ini mencoba mendesain model pengukuran kinerja Rumah Sakit dengan menggunakan pendekatan BSC, serta mencoba untuk merumuskan bobot dan skor yang nantinya bisa dijadikan sebagai acuan oleh setiap Rumah Sakit di Seluruh Indonesia pada umunya, maupun di wilayah Nusa Tenggara Barat pada khususnya. Berdasarkan uraian pada latar belakang, maka dapat dirumuskan suatu permasalah dalam penelitian ini antara lain bagaimakah model penilaian kinerja Rumah Sakit dengan pendekatan Balanced Scorecard dan berapakah besaran bobot dan skor untuk penilaian kinerja Rumah Sakit dengan pendekatan Balanced Scorecard?.

\section{TELAAH LITERATUR DAN PENGEMBANGAN HIPOTESIS}

\section{Konsep Balanced Scorecard}

Balanced scorecard merupakan suatu konsep yang bertujuan untuk mendukung perwujudan visi, misi, dan strategi perusahaan dengan menekankan pada empat kajian yaitu perspektif keuangan (financial, pelanggan (customer), bisnis internal (internal business), serta pembelajaran dan pertumbuhan (learning and growth) dengan target bersifat jangka panjang. Balanced scorecard terdiri dari dua kata yaitu balanced artinya berimbang dan scorecard artinya kartu skor. Kartu skor adalah kartu yang digunakan untuk mencatat skor hasil kinerja suatu organisasi atau skor 
Effendy, Hilendria \& Isnawati: Balanced Scrocard (BSC)...

individu. Kata berimbang dimaksudkan untuk menunjukkan bahwa kinerja organisasi/individu diukur secara berimbang dari dua aspek yaitu keuangan dan non keuangan, jangka pendek dan jangka panjang, internal dan eksternal (Fahmi, 2013:209).

Balanced scorecard merupakan metode perencanaan dan penilaian yang mencakup empat perspektif perusahaan, yaitu perspektif keuangan, perspektif pelanggan, perspektif proses bisnis internal, dan perspektif pembelajaran dan pertumbuhan. Tujuan perencanaan dan pengukuran dalam balanced scorecard bukan hanya penggabungan ukuran-ukuran keuangan dan non keuangan yang ada saja, melainkan juga merupakan hasil proses atas bawah berdasarkan misi dan strategi dari suatu unit usaha (Rudianto, 2013:235).

Balanced scorecard merupakan contoh sistem pengukuran kinerja. Balanced scorecard pertama kali diperkenalkan oleh Kaplan dan Norton. Ia menekankan keseimbangan antara ukuran strategis dalam upaya mencapai keselarasan tujuan, sehingga mendorong bawahan untuk bertindak sesuai dengan tujuan perusahaan. Untuk mendukung keselarasan tujuan, balanced scorecard merupakan alat dalam memfokuskan organisasi, meningkatkan komunikasi, menetapkan tujuan organisasi, dan menyediakan umpan balik bagi manajemen (Halim et al., 2000:209).

Balanced scorecard terdiri dari kumpulan ukuran kinerja yang terintegrasi yang diturunkan dari strategi perusahaan yang mendukung strategi perusahaan secara keseluruhan. Menurut pendekatan balanced scorecard, manajemen atas menerjemahkan strategi mereka ke dalam ukuran kinerja yang dapat dipahami dan dilakukan oleh para karyawan (Garrison dan Noreen, diterjemahkan oleh A. Totok Budisantoso, 2000:494-495). 


\section{Keunggulan Balanced Scorecard}

Keunggulan balanced scorecard dibandingkan dengan pengukuran kinerja tradisional adalah :

1. Merupakan konsep pengukuran yang komprehensif. Balanced scorecard menekankan pengukuran kinerja tidak hanya pada aspek kuantitatif saja, tetapi juga aspek kualitatif.

2. Merupakan konsep yang adaptif dan responsif terhadap lingkungan bisnis. Memberikan fokus terhadap tujuan menyeluruh perusahaan (Halim et al., 2000:217).

\section{Perspektif Balanced Scorecard}

Pengukuran kinerja organisasi menggunakan Balanced Scorecard ini menekankan pada empat (4) perspektif:

\section{Perspektif Keuangan}

Perspektif keuangan mengukur kinerja perusahaan dalam memperoleh laba dan nilai pasar. Ukuran keuangan biasanya diwujudkan dalam profitabilitas, pertumbuhan, dan nilai pemegang saham (Halim et al.,, 2000:212). Perspektif keuangan digunakan karena ukuran keuangan sangat penting dalam memberikan ringkasan konsekuensi tindakan ekonomis yang sudah diambil. Ukuran kinerja keuangan memberikan petunjuk apakah strategi perusahaan, implementasi, dan pelaksanaannya memberikan kontribusi atau tidak kepada peningkatan laba perusahaan. Tujuan keuangan biasanya berhubungan dengan profitabilitas. Tujuan keuangan lainnya adalah pertumbuhan penjualan yang cepat atau terciptanya arus kas (Rudianto, 2013:239).

Pengukuran kinerja Rumah Sakit dari perspektif keuangan rasio-rasio keuangan yang didasarkan pada Keputusan Menteri Kesehatan RI Nomor 
Effendy, Hilendria \& Isnawati: Balanced Scrocard (BSC)...

1981/MENKES/SK/XII/2010 seperti :a) Rasio Likuiditas; b) Rasio Aktivitas;

c) Rasio Solvabilitas; d) Rasio profitabilitas.

\section{Perspektif Pelanggan}

Perspektif pelanggan diukur dari bagaimana perusahaan dapat memuaskan pelanggan. Alat ukur yang biasa digunakan adalah market share, customer retention, customer acquisition, customer satisfaction, dan customer probability (Halim et al.,, 2000:213). Perspektif pelanggan mengidentifikasi bagaimana kondisi pelanggan dan segmen pasar yang telah dipilih oleh perusahaan untuk bersaing dengan kompetitor. Perspektif ini biasanya terdiri atas beberapa ukuran utama atau ukuran generik keberhasilan perusahaan dari strategi yang dirumuskan dan dilaksanakan dengan baik. Alat ukur untuk perspektif pelanggan ini pada Rumah Sakit biasanya menggunakan : a) Retensi Pasien ; b) Akuisisi Pasien ; c) Kepuasan Pasien.

\section{Perspektif Proses Bisnis Internal}

Perspektif ini, kinerja perusahaan diukur dari bagaimana perusahaan dapat menghasilkan produk atau jasa secara efisien dan efektif. Ukuran yang biasa digunakan adalah kualitas, response time, cost, dan pengenalan produk baru (Halim et al.,, 2000:213). Perspektif proses bisnis internal dilakukan dengan cara perusahaan melakukan pengukuran terhadap semua aktivitas yang dilakukan oleh perusahaan, baik oleh manajer maupun karyawan demi menciptakan produk yang dapat memberikan kepuasan tertentu bagi pelanggan dan juga para pemegang saham. Alat ukur untuk perspektif Bisnis Internal pada Rumah Sakit berdasarkan Peraturan Menteri Kesehatan RI No.1171/MENKES/Per/VI/2011 yang paling sering digunakan antara lain: a) BTO (Bed Turn Over); b) BOR (Bed 
Occupancy Rate) ; c) TOI (Turn Over Internal); d) NDR (Net Death Rate); e) GDR (Gross Dath Rate); f) ALOS (Average Length of Stay).

\section{Perspektif Pertumbuhan dan Pembelajaran}

Perspektif ini menekankan pada bagaimana perusahaan dapat berinovasi dan terus tumbuh dan berkembang agar dapat bersaing di masa sekarang maupun yang akan datang. Oleh karena itu sumber daya dituntut untuk produktif dan terus belajar agar mempunyai kemampuan dalam berinovasi dan mengembangkan produk baru yang memiliki value bagi customer. Alat ukur yang biasa dipakai adalah employee satisfaction dan information system available (Halim et al.,, 2000:213-214). Alat ukur yang umumnya digunakan untuk perspektif Pertumbuhan dan pembelajaran pada Rumah Saki tantara lain: a) Retensi Karyawan; b) Kepuasan Karyawan; c) Ketersediaan Informasi Strategis; d) Tingkat Kehadiran Karyawan.

\section{Konsep Kinerja}

Menurut Mangkunegara (2005:59) pengertian kinerja adalah hasil kerjaecara kualitas dan kuantitas yang dicapai oleh pegawai dalam melaksanakan tugasnya sesuai dengan tanggung jawab yang diberikan. Kinerja adalah hasil kerja yang dapat dicapai oleh seseorang atau kelompok orang dalam suatu perrusahaan sesuai dengan wewenang dan tanggung jawab masing-masing dalam upaya pencapaian tujuan Rumah Sakit secara legal, tidak melanggar hukum dan tidak bertentangan dengan moral atau etika. Menurut D.Stout (dalam Yuwono,2002:65) mengatakan bahwa pengukuran kinerja merupakan proses mencatat dan mengukur pencapaian pelaksanaan kegiatan dalam arah pencapaian misi melalui hasil-hasil yang ditampilkan berupa produk, jasa ataupun suatu proses. Mencatat dan mengukur pencapaian kegiatan dalam arah pencapaian visi dan misi 
Effendy, Hilendria \& Isnawati: Balanced Scrocard (BSC)...

organisasi. Pengukuran kinerja Rumah Sakit yang hanya ditekankan pada sudut pandang keuangan, sering menghilangkan sudut pandang lain yang tidak kalah pentingnya sehingga akan meninggalkan suatu kesenjangan antara pengembang suatu strategi dan implikasinya.

\section{Tujuan dan Manfaat Kinerja}

Pengukuran kinerja mempunyai tugas pokok yaitu untuk memotivasi karyawan dalam pencapaian sasaran organisasi dengan tetap mematuhi standar perilaku yang telah ditetapkan sebelumnya, agar membuahkan tindakan dan hasil yang diinginkan (Mardiasmo,2002:122). Secara umum, tujuan pengukuran kinerja adalah sebagai berikut :

1. Mengkomunikasikan strategi secara lebih mantap.

2. Mengukur kerja finansial dan nonfinansial secara berimbang, sehingga dapat ditelusuri perkembangan pencapaian strategi.

3. Mengakomodasi pemahaman kepentingan manajer level menengah dan bawah serta memotivasi untuk mencapai goal congruence.

4. Alat untuk mencapai kepuasaan berdasarkan pendekatan individual dan kemampuan kolektif rasional.

Menurut Uhum (2009:22) Manfaat pengukuran kinerja baik untuk internal maupun eksternal organisasi:

1. Memastikan pemahaman para pelaksana akan ukuran yang digunakan untuk pencapaian kinerja.

2. Memastikan tercapainya rencana kinerja yang telah disepakati.

3. Memantau dan mengevaluasi pelaksanaan kinerja dan membandingkannya dengan rencana kerja serta melakukan tindakan untuk memperbaiki kinerja.

4. Memberikan penghargaan dan hukuman yang obyektif atas prestasi pelaksana yang telah diukur sesuai dengan sistem pengukuran kinerja yang telah disepakati. 
5. Menjadi alat komunikasi antara bawahan dan pimpinan dalam upaya memperbaiki kinerja organisasi.

6. Mengidentifikasi apakah kepuasaan pelanggan sudah terpenuhi.

7. Membantu memahami proses kegiatan instansi kepolisian

8. Memastikan bahwa pengambilan keputusan dilakukan secara obyektif.

9. Menunjukkan peningkatan yang telah perlu dilakukan.

10. Mengungkapkan permasalahan yang terjadi.

\section{METODE PENELITIAN}

\section{Jenis Penelitian}

Penelitian ini merupakan studi deskriptif. Studi Deskriptif dilakukan untuk mengetahui dan menjelaskan karakteristik variable yang diteliti dalam suatu situasi.

\section{Lokasi Penelitian}

Penelitian ini mencoba memetakan hasil-hasil penelitian tentang pengukuran Kinerja Rumah Sakit yang berada dalam wilayah Negara Indonesia dengan menggunakan konsep BSC, untuk nantinya dijadikan sebagai bahan dalam merumuskan bobot pemberian skor pada BSC Rumah Sakit. Dengan demikian lokasi yang diambil dalam penelitian ini adalah wilayah Indonesia.

\section{Sumber Data Penelitian}

Penelitian ini menggunakan data sekunder. Data sekunder dalam penelitian ini dapat diperoleh dari sumber pustaka seperti buku, dokumendokumen pihak terkait, maupun sumber dari media lain yang dapat 
Effendy, Hilendria \& Isnawati: Balanced Scrocard (BSC)...

menunjang kelengkapan data penelitian agar penelitian ini dapat berjalan akurat dan sesuai dengan kenyataannya.

\section{Teknik Pengumpulan Data}

Sesuai dengan jenis penelitian deskriptif dan sumber data yang akan digunakan, maka teknik pengumpulan data yang digunakan adalah dengan analisis dokumen.

\section{Populasi dan sampel}

Populasi dalam penelitian ini adalah semua penelitian di Seluruh Indonesia yang mengangkat tema pengukuran Kinerja Rumah Sakit dengan pendekatan Balanced Scorecard. Sampel penelitian meliputi sejumlah elemen (responden) yang lebih besar dari persyaratan minimal sebanyak 30 elemen/responden. Menurut Guilford (1987:125) dalam (Supranto, 2006239), dimana semakin besar sampel (makin besar nilai $n=$ banyaknya elemen sampel), akan memberikan hasil yang lebih akurat. Pada penelitian ini menggunakan metode Accidental Sampling yaitu penentuan sampel tanpa sengaja. Dimana peneliti mengambil sampel yang kebetulan ditemuinya pada saat itu (browsing), namun jumlah sampel tentunya diharapkan diatas 30 responden.

\section{Analisis Data}

Metode analisis data untuk mengetahui arah penelitian ini, secara garis besar dapat dilihat pada gambar 2. Tahap pertama adalah mengumpulkan data publikasi literatur ilmiah meliputi jurnal, buku dan prosiidng di seluruh Indonesia tentang pengukuran kinerja Rumah Sakit dengan pendekatan Balanced Scorecard. Hasil pencarian kemudian disaring/dipilah menurut metode penelitian, aspek penelitian dan bidang industry penerapan. Pemilahan dilakukan dengan membaca dan memahami penelitian berdasar 
metode penelitian menggunakan acuan dari Kothari (2004). Sedangkan kategori Metode penelitian berdasarkan Kothari, (2004) dapat dilihat pada tabel 1di bawah ini:

Tabel 1: Kategori Metode Penelitian (Kothari;2004)

\begin{tabular}{|c|c|}
\hline Kategori & Penjelasan \\
\hline Metode & \\
\hline Penelitian & \\
\hline Deskriptif & $\begin{array}{l}\text { Penelitian bertujuan mengidentifikasi } \\
\text { temuan berdasar fakta dan informasi }\end{array}$ \\
\hline Konseptual & $\begin{array}{l}\text { Penelitian bertujuan untuk menghasilkan } \\
\text { konsep atau ide }\end{array}$ \\
\hline Terapan & $\begin{array}{l}\text { Penelitian bertujuan mencari solusi dari } \\
\text { masalah yang dihadapi di Industri dan bisa } \\
\text { langsung diterapkan }\end{array}$ \\
\hline Empirikal & $\begin{array}{l}\text { Pembuktian hipotesis dengan cara } \\
\text { pengumpulan data hasil observasi ataupun } \\
\text { eksperimen }\end{array}$ \\
\hline Simulasi & $\begin{array}{l}\text { Pembuktian hipotesis dengan cara } \\
\text { membuat simulasi dari system riil yang } \\
\text { diteliti. }\end{array}$ \\
\hline
\end{tabular}

\section{HASIL PENELITIAN DAN PEMBAHASAN}

\section{Gambaran Data Penelitian}

Penelitian ini mencoba memetakan rumusan penilaian kinerja Rumah Sakit dengan pendekatan Balanced Scorecard (BSC). Penilaian kinerja dengan pendekatan BSC ini menggunakan empat (4) perspektif, yaitu Perspektif keuangan; Perspektif Pelanggan; Perspektif Proses Bisnis Internal; Perspektif 
Effendy, Hilendria \& Isnawati: Balanced Scrocard (BSC)...

Pertumbuhan dan pembelajaran. Berikut adalah gambaran penilaian kinerja Rumah Sakit di Indonesia dengan menggunakan 4 perspektif tersebut.

\section{Perspektif keuangan}

Perspektif keuangan digunakan karena ukuran keuangan sangat penting dalam memberikan ringkasan konsekuensi tindakan ekonomis yang sudah diambil. Ukuran kinerja keuangan memberikan petunjuk apakah strategi perusahaan, implementasi, dan pelaksanaannya memberikan kontribusi atau tidak kepada peningkatan laba perusahaan. Tujuan keuangan biasanya berhubungan dengan profitabilitas. Tujuan keuangan lainnya adalah pertumbuhan penjualan yang cepat atau terciptanya arus kas (Rudianto, 2013:239). Maka berikut adalah beberapa alat yang dapat digunakan untu mengukur perhitungan kinerja Rumah Sakit dari perspektif keuangan:

- Anggaran Belanja Tidak Langsung

- Anggaran Belanja Operasi

- Anggaran Belanja Langsung

- Rasio Ekonomis

- Rasio Efisiensi

- Rasio Efektifitas

- Kolektibilitas Piutang

- Pertumbuhan Pendapatan

- Pertumbuhan Laba

- Rasio Lancar (Current Ratio)

- Rasio Cepat (Quick ratio)

- Rasio Hutang terhadap Ekuitas (iDebt to equity ratio)

- Rasio Hutang terhadap Harta (Total Debt to Asset ratio)

- Return on Asset (ROA) 


\section{Perspektif pelanggan}

Perspektif pelanggan diukur dari bagaimana perusahaan dapat memuaskan pelanggan. Perspektif pelanggan mengidentifikasi bagaimana kondisi pelanggan dan segmen pasar yang telah dipilih oleh perusahaan untuk bersaing dengan kompetitor. Perspektif ini biasanya terdiri atas beberapa ukuran utama atau ukuran generik keberhasilan perusahaan dari strategi yang dirumuskan dan dilaksanakan dengan baik. Maka berikut adalah beberapa alat yang dapat digunakan untu mengukur perhitungan kinerja Rumah Sakit dari perspektif Pelanggan:

- Tingkat Kepuasan Pasien

- Tingkat Retensi Pasien

- Tingkat Akuisisi Pasien

- Pertumbuhan Kunjungan Pasien

\section{Perspektif Bisnis Internal}

Perspektif ini, kinerja perusahaan diukur dari bagaimana perusahaan dapat menghasilkan produk atau jasa secara efisien dan efektif. Perspektif proses bisnis internal dilakukan dengan cara perusahaan melakukan pengukuran terhadap semua aktivitas yang dilakukan oleh perusahaan, baik oleh manajer maupun karyawan demi menciptakan produk yang dapat memberikan kepuasan tertentu bagi pelanggan dan juga para pemegang saham. Berikut adalah beberapa alat yang dapat digunakan untu mengukur perhitungan kinerja Rumah Sakit dari perspektif Bisnis Internal:

- Tingkat Inovasi

- ALOS (Average Length of Stay)

- BOR (Bed Occupancy Rate)

- TOI (Turn Over Interval)

- BTO (Bed Turn Overrate) 
Effendy, Hilendria \& Isnawati: Balanced Scrocard (BSC)...

- NDR (Net Death Rate)

- GDR (Gross Death Rate)

- Mutu waktu tunggu layanan obat

- Mutu angka infeksi luka operasi

- Mutu angka keterlambatan penanganan IGD

- Mutu angka waktu tunggu operasi

- Pertumbuhan jumlah pasien

\section{Perspektif Pertumbuhan dan pembelajaran}

Perspektif ini menekankan pada bagaimana perusahaan dapat berinovasi dan terus tumbuh dan berkembang agar dapat bersaing di masa sekarang maupun yang akan datang. Oleh karena itu sumber daya dituntut untuk produktif dan terus belajar agar mempunyai kemampuan dalam berinovasi dan mengembangkan produk baru yang memiliki value bagi customer. Berikut adalah beberapa alat yang dapat digunakan untu mengukur perhitungan kinerja Rumah Sakit dari perspektif pertumbuhan dan pembelajaran:

- Tingkat Kepuasan Karyawan

- Kapabilitas Pekerja/ produktivitas Karyawan

- Kapabilitas Sistem Informasi

- Tingkat motivasi karyawan

- Tingkat Retensi Karyawan

\section{Analisis Data}

Salah satu tujuan dari penelitian ini adalah untuk mengetahui model penilaian kinerja dengan pendekatan BSC (Balanced Scorecard) yang mengandalkan pada empat (4) perspektif, yaitu: a) perspektif keuangan; b) perspektif pelanggan (pasien); c) perspektif bisnis internal; dan d) perspektif pertumbuhan dan pembelajaran. Dan berdasarkan pada uraian gambaran data 
penelitian, maka berikut dapat dikemukakan model penilaian kinerja rumah sakit dari perspektif keuangan.

\section{Model Penilaian Kinerja Rumah Sakit Perspektif Keuangan}

Perspektif keuangan menunjukkan kemampuan manajemen Rumah Sakit dalam mencapai kondisi keuangannya. Untuk melihat tingkat pencapaian tersebut, maka dapat digunakan beberapa model perhitungan.

Berdasarkan pada Keputusan Menteri Kesehatan Republik Indonesia Nomor 1981/MENKES/SK/XII/2010, yaitu menggunakan rasio-rasio keuangan. Namun berdasarkan kajian literatur yang ada terkait penilaian kinerja Rumah Sakit dengan pendekatan BSC, maka berikut adalah alat ukur yang paling banyak digunakan dalam menilai perspektif keuangan:
a. Rasio Ekonomis
b. Rasio Efisiensi
c. Rasio Efektifitas

\section{Model Penilaian Kinerja Rumah Sakit Perspektif Pelanggan (Pasien)}

Perspektif ini mengukur sejauh mana organisasi mampu memuaskan pelanggan. Pengukuran kepuasan pasien tidak diatur dalam aturan Menteri Kesehatan, maka pengukuran kinerja dari perspektif pasien disesuaikan dengan konsep yang dijelaskan oleh Kaplan dan Norton mengenai kepuasan pelanggan. Dan berikut adalah rumusan alat ukur yang paling banyak digunakan dalam pengukuran kinerja Rumah Sakit dari perspektif Pasien (pelanggan)

a. Retensi Pasien

Retensi Pasien yaitu kemampuan rumah sakit untuk mempertahankan hubungan dengan pasien lamanya. Retensi pasien dinilai baik bila hasil 
Effendy, Hilendria \& Isnawati: Balanced Scrocard (BSC)...

perhitungan selama periode pengamatan mengalami peningkatan, dinilai cukup baik apabila konstan, dan dinilai kurang apabila mengalami penurunan.

b. Akuisisi Pasien

Akuisisi pasien yaitu kemampuan rumah sakit untuk dapat menarik pasien barunya. Akuisisi pasien dinilai baik bila hasil perhitungan selama periode pengamatan mengalami peningkatan, dinilai cukup baik apabila konstan, dan dinilai kurang apabila mengalami penurunan.

c. Kepuasan Pasien

Kepuasan pasien yaitu mengukur seberapa jauh kepuasan pasien atas pelayanan kesehatan yang diberikan rumah sakit. Kepuasan pasien dapat dilihat dari hasil penyebaran kuesioner.

\section{Model Penilaian Kinerja Rumah Sakit Perspektif Bisnis Internal}

Dalam perspektif ini, kinerja perusahaan diukur dari bagaimana perusahaan dapat menghasilkan produk atau jasa secara efisien dan efektif. Ukuran yang biasa digunakan adalah kualitas, response time, cost, dan pengenalan produk baru (Halim et al.,, 2000:213). Berdasarkan Peraturan Menteri Kesehatan Republik Indonesia Nomor

1171/MENKES/PER/VI/2011, mengatur tentang mutu operasional Rumah Sakit, sehingga rumusan ini sering digunakan untuk menilai kinerja Rumah Sakit dari Perspektif Bisnis internal, yaitu:

- BTO (Bed Turn Over) yaitu frekuensi pemakaian tempat tidur pada satu periode, berapa kali tempat tidur dipakai dalam satu satuan waktu (biasanya dalam periode 1 tahun). Indikator ini memberikan tingkat efisiensi pada pemakaian tempat tidur. Idealnya dalam satu tahun, satu tempat tidur rata-rata dipakai 40-50 kali.

- BOR (Bed Occupancy Rate) yaitu persentase pemakaian tempat tidur pada satu satuan waktu tertentu. Indikator ini memberikan gambaran 
tinggi rendahnya tingkat pemanfaatan tempat tidur rumah sakit. Nilai parameter BOR yang ideal adalah antara $60-85 \%$.

- TOI (Turn Over Interval) yaitu rata-rata hari di mana tempat tidur tidak ditempati dari telah diisi ke saat terisi berikutnya. Indikator ini juga memberikan gambaran tingkat efisiensi penggunaan tempat tidur. Idealnya tempat tidur kosong/tidak terisi pada kisaran 1-3 hari.

- NDR (Net Death Rate) yaitu angka kematian 48 jam setelah dirawat untuk tiap-tiap 1000 penderita keluar. Indikator ini memberikan gambaran mutu pelayanan di rumah sakit. Secara umum nilai standar NDR adalah kurang dari 25/1000.

- GDR (Gross Death Rate) yaitu angka kematian umum untuk setiap 1000 penderita keluar rumah sakit. Secara umum nilai standar GDR adalah tidak lebih dari 45/1000 penderita keluar.

- ALOS (Average Length of Stay) yaitu rata-rata lama rawat seorang pasien. Indikator ini di samping memberikan gambaran tingkat efisiensi, juga dapat memberikan gambaran mutu pelayanan, apabila diterapkan pada diagnosis tertentu dapat dijadikan hal yang perlu pengamatan yang lebih lanjut. Secara umum nilai ALOS yang ideal antara 6-9 hari.

\section{Model Penilaian Kinerja Rumah Sakit Perspektif Pertumbuhan dan Pembelajaran}

Perspektif ini menekankan pada bagaimana perusahaan dapat berinovasi dan terus tumbuh dan berkembang agar dapat bersaing di masa sekarang maupun yang akan datang. Oleh karena itu sumber daya dituntut untuk produktif dan terus belajar agar mempunyai kemampuan dalam berinovasi dan mengembangkan produk baru yang memiliki value bagi customer. Alat ukur yang biasa dipakai adalah employee satisfaction dan information 
Effendy, Hilendria \& Isnawati: Balanced Scrocard (BSC)...

system available (Halim et al.,, 2000:213-214). Berdasarkan kajian literatur tentang penilaian kinerja Rumah Sakit dengan BSC, maka berikut adalah rumusan / alat ukur yang paling banyak digunakan untuk menilai kinerja Rumah Sakit dari perspektif pertumbuhan dan pembelajaran:

1. Retensi Karyawan

Retensi karyawan mengukur seberapa kemampuan rumah sakit dalam mempertahankan karyawan yang kompeten. Retensi karyawan dinilai baik bila selama periode pengamatan hasil perhitungan mengalami penurunan, dinilai cukup baik apabila konstan, dan dinilai kurang apabila mengalami peningkatan (Suprapto, et al., dalam Lestari (2016)).

2. Kepuasan karyawan

Kepuasan karyawan yaitu untuk mengetahui seberapa jauh kepuasan karyawan terhadap apa yang diberikan oleh pihak manajemen rumah sakit. Kepuasan karyawan dapat dilihat dari hasil penyebaran kuesioner.

\section{Interpretasi}

Model Penilaian Kinerja Rumah Sakit dengan Pendekatan Balanced Scorecard

Salah satu tujuan dari penelitian ini adalah untuk merumuskan model penilaian kinerja Rumah Sakit dengan pendekatan Balanced Scorecard (BSC) yang dirumuskan dari pengukuran kinerja Rumah Sakit yang ada di Indoenesia dengan pendekatan BSC tersebut. Berdasarkan penjelasan pada pembahasan, maka berikut ini adalah rumusan (model) penilaian kinerja Rumah Sakit dengan menggunakan pendekatan 4 perspektif:

Tabel 4.5: Rumusan Penilaian Kinerja Rumah Sakit Pendekatan Balanced Scorecard (BSC) 


\begin{tabular}{ll}
\hline Perspektif Penilaian & Rumusan Penilaian \\
\hline Perspektif Keuangan & $*$ Rasio Ekonomis \\
& $*$ Rasio Efektifitas \\
& $*$ Rasio Efisiensi \\
& $*$ Tingkat Ketensiasan Pasien \\
& $*$ Akuisisi Pasien \\
\hline Perspektif Bisnis Internal & $*$ ALOS \\
& $*$ BOR \\
& $*$ TOI \\
& $*$ BTO \\
& $*$ NDR \\
& $*$ GDR \\
& $*$ Tingkat Inovasi \\
\hline Perspektif Pertumbuhan dan & $*$ Tingkat Kepuasan \\
kembelajaran & $*$ Tingkat \\
& Karyawan \\
\hline & $2019)$
\end{tabular}

Sumber : Data Sekunder (diolah : 2019)

Besaran Bobot dan Skor untuk Penilaian Kinerja Rumah Sakit dengan Pendekatan Balanced Scorecard

Tjuan lain dari penelitian ini adalah untuk merumuskan kriteria skor penilaian kinerja Rumah Sakit dengan pendekatan Balanced Scorecard (BSC) yang dirumuskan dari pengukuran kinerja Rumah Sakit yang ada di Indoenesia dengan pendekatan BSC tersebut. Berdasarkan penjelasan pada pembahasan, maka berikut ini adalah rumusan kriteria skor penilaian kinerja Rumah Sakit dengan menggunakan pendekatan 4 perspektif: 
Effendy, Hilendria \& Isnawati: Balanced Scrocard (BSC)...

Tabel 4.6: Besaran Bobot / Skor Penilaian Kinerja Rumah Sakit

Pendekatan Balanced Scorecard (BSC)

\begin{tabular}{|c|c|c|c|}
\hline $\begin{array}{l}\text { Perspektif } \\
\text { keuangan }\end{array}$ & Kriteria & Bobot & Skor \\
\hline Rasio & $<100 \%$ (ekonomis) & $8,33 \%$ & $(3 / 3) \times$ \\
\hline \multirow[t]{5}{*}{ Ekonomis } & $=(3 / 3)$ & & $8,33 \%$ \\
\hline & $=100 \%$ (ekonomis & & $(2 / 3) \times$ \\
\hline & berimbang $)=(2 / 3)$ & & $8,33 \%$ \\
\hline & $>100 \%$ (tidak ekonomis) & & $(1 / 3) \times$ \\
\hline & $=(1 / 3)$ & & $8,33 \%$ \\
\hline \multirow[t]{6}{*}{ Rasio Efisien } & $<100 \%$ (efisien) $=(3 / 3)$ & $8,33 \%$ & $(3 / 3) \times$ \\
\hline & $=100 \%$ (efisien & & $8,33 \%$ \\
\hline & berimbang $)=(2 / 3)$ & & $(2 / 3) \times$ \\
\hline & $>100 \%($ tidak efisien $)=$ & & $8,33 \%$ \\
\hline & $(1 / 3)$ & & $(1 / 3) \times$ \\
\hline & & & $8,33 \%$ \\
\hline \multirow[t]{6}{*}{ Rasio Efektif } & $>100 \%$ (efektif) $=(3 / 3)$ & $8,33 \%$ & $(3 / 3) \times$ \\
\hline & $=100 \%$ (efektif & & $8,33 \%$ \\
\hline & berimbang $)=(2 / 3)$ & & $(2 / 3) \times$ \\
\hline & $<100 \%$ (tidak efektif $)=$ & & $8,33 \%$ \\
\hline & $(1 / 3)$ & & $(1 / 3) \times$ \\
\hline & & & $8,33 \%$ \\
\hline
\end{tabular}

\begin{tabular}{llll}
\hline $\begin{array}{l}\text { Perspektif } \\
\text { Pasien }\end{array}$ & Kriteria & Bobot & Skor \\
\hline Tingkat & $1-1.80:$ Sangat Tidak & $8,33 \%$ & $(5 / 5) \times$ \\
Kepuasan & Puas (1/5) & & $8,33 \%$ \\
Pasien & & & \\
\hline
\end{tabular}




\begin{tabular}{|c|c|c|c|}
\hline & $1,80-2,60:$ Tidak Puas & & $(4 / 5) \times$ \\
\hline & $(2 / 5)$ & & $8,33 \%$ \\
\hline & $2,60-3,40$ : Biasa Saja & & $(3 / 5) x$ \\
\hline & $(3 / 5)$ & & $8,33 \%$ \\
\hline & $3,40-4,20$ : Puas $(4 / 5)$ & & $(2 / 5) x$ \\
\hline & $4,20-5,00$ : Sangat Puas & & $8,33 \%$ \\
\hline & $(5 / 5)$ & & $(1 / 5) x$ \\
\hline & & & $8,33 \%$ \\
\hline Retensi & $>$ Tahun $\mathrm{n}-1$ = Sangat & $8,33 \%$ & $(3 / 3) x$ \\
\hline Pasien & Baik $(3 / 3)$ & & $8,33 \%$ \\
\hline & $=$ Tahun $n-1=$ Baik $(2 / 3)$ & & $(2 / 3) \times$ \\
\hline & $<$ Tahun n-1 = Tidak Baik & & $8,33 \%$ \\
\hline & $(1 / 3)$ & & $(1 / 3) x$ \\
\hline & & & $8,33 \%$ \\
\hline Akuisisi & $>$ Tahun $\mathrm{n}-1$ = Sangat & $8,33 \%$ & $(3 / 3) x$ \\
\hline Pasien & Baik (3/3) & & $8,33 \%$ \\
\hline & $=$ Tahun $n-1=$ Baik $(2 / 3)$ & & $(2 / 3) x$ \\
\hline & $<$ Tahun n-1 = Tidak Baik & & $8,33 \%$ \\
\hline & $(1 / 3)$ & & $(1 / 3) x$ \\
\hline & & & $8,33 \%$ \\
\hline
\end{tabular}

\begin{tabular}{llll}
\hline Perspektif Kriteria & Bobot Skor
\end{tabular}

Bisnis

Internal

\begin{tabular}{|c|c|c|c|}
\hline \multirow[t]{4}{*}{ ALOS } & 6-9 hari : Ideal $(2 / 2)$ & $3,57 \%$ & $(2 / 2) x$ \\
\hline & $<6$ atau $>9$ hari : tidak & & $3,57 \%$ \\
\hline & Ideal $(1 / 2)$ & & $(1 / 2) x$ \\
\hline & & & $3,57 \%$ \\
\hline
\end{tabular}


Effendy, Hilendria \& Isnawati: Balanced Scrocard (BSC)...

\begin{tabular}{|c|c|c|c|}
\hline BOR & $60-80 \%:$ Ideal $(2 / 2)$ & $3,57 \%$ & $(2 / 2) \times$ \\
\hline & $<60$ atau $>80 \%$ : tidak & & $3,57 \%$ \\
\hline & Ideal $(1 / 2)$ & & $(1 / 2) x$ \\
\hline & & & $3,57 \%$ \\
\hline TOI & 1 - 3 hari : Ideal (2/2) & $3,57 \%$ & $(2 / 2) x$ \\
\hline & $<1$ atau $>$ 3hari : Tidak & & $3,57 \%$ \\
\hline & Ideal (1/2) & & $(1 / 2) x$ \\
\hline & & & $3,57 \%$ \\
\hline BTO & 40 - 50 kali : Ideal (2/2) & $3,57 \%$ & $(2 / 2) x$ \\
\hline & $<40$ atau $>50$ kali : & & $3,57 \%$ \\
\hline & Tidak Ideal (1/2) & & $(1 / 2) x$ \\
\hline & & & $3,57 \%$ \\
\hline NDR & $<(25 / 1000):$ Ideal $(2 / 2)$ & $3,57 \%$ & $(2 / 2) \times$ \\
\hline & $>(25 / 1000):$ Tidak Ideal & & $3,57 \%$ \\
\hline & $(1 / 2)$ & & $(1 / 2) x$ \\
\hline & & & $3,57 \%$ \\
\hline GDR & $</=(45 / 1000):$ Ideal & $3,57 \%$ & $(2 / 2) \times$ \\
\hline & $(2 / 2)$ & & $3,57 \%$ \\
\hline & $>(45 / 1000):$ Tidak Ideal & & $(1 / 2) x$ \\
\hline & $(1 / 2)$ & & $3,57 \%$ \\
\hline Tingkat & $>75 \%$ : Istimewa (4/4) & $3,57 \%$ & $(4 / 4) x$ \\
\hline Inovasi & $</=75 \%:$ Baik $(3 / 4)$ & & $3,57 \%$ \\
\hline & $</=50 \%$ : Cukup Baik & & $(3 / 4) x$ \\
\hline & $(2 / 4)$ & & $3,57 \%$ \\
\hline & $</=25 \%$ : Tidak Baik & & $(2 / 4) \times$ \\
\hline & $(1 / 4)$ & & $3,57 \%$ \\
\hline & & & $(1 / 4) x$ \\
\hline & & & $3,57 \%$ \\
\hline
\end{tabular}




\begin{tabular}{|c|c|c|c|}
\hline $\begin{array}{l}\text { Perspektif } \\
\text { Pertumbuh } \\
\text { dan } \\
\text { pembelajar }\end{array}$ & Kriteria & Bobot & Skor \\
\hline Tingkat & 1-1.80 : Sangat Tidak & $12,5 \%$ & $(5 / 5) \times$ \\
\hline Kepuasan & Puas $(1 / 5)$ & & $12,5 \%$ \\
\hline \multirow[t]{8}{*}{ Karyawan } & 1,80 - 2,60 : Tidak Puas & & $(4 / 5) \times$ \\
\hline & $(2 / 5)$ & & $12,5 \%$ \\
\hline & 2,60 - 3,40 : Biasa Saja & & $(3 / 5) x$ \\
\hline & $(3 / 5)$ & & $12,5 \%$ \\
\hline & $3,40-4,20:$ Puas $(4 / 5)$ & & $(2 / 5) x$ \\
\hline & $4,20-5,00$ : Sangat & & $12,5 \%$ \\
\hline & Puas $(5 / 5)$ & & $(1 / 5) x$ \\
\hline & & & $12,5 \%$ \\
\hline Tingkat & $<1$ : Sangat Baik (3/3) & $12,5 \%$ & $(3 / 3) x$ \\
\hline Retensi & $=1:$ Baik $(2 / 3)$ & & $12,5 \%$ \\
\hline \multirow[t]{4}{*}{ Karyawan } & > 1 : Tidak Baik (1/3) & & $(2 / 3) x$ \\
\hline & & & $12,5 \%$ \\
\hline & & & $(1 / 3) x$ \\
\hline & & & $12,5 \%$ \\
\hline
\end{tabular}

Kriteria Kesimpulan Kinerja Rumah Sakit dengan Pendekatan BSC

\begin{tabular}{ll}
\hline Kriteria & Kesimpulan \\
\hline $100 \%-86,32$ & Sangat Baik \\
$\%$ & \\
\hline $86,32 \%-$ & Baik \\
$72.64 \%$ & \\
\hline
\end{tabular}


Effendy, Hilendria \& Isnawati: Balanced Scrocard (BSC)...

$72,64 \%$ - Biasa Saja

$58,96 \%$

$58,96 \%-\quad$ Tidak Baik

$45,28 \%$

$45,28 \%-\quad$ Sangat Tidak

$31,60 \% \quad$ Baik

Sumber : Data Sekunder (diolah : 2019)

\section{SIMPULAN}

Berdasarkan uraian pada pembahasan, maka dapat ditarik beberapa kesimpulan dalam penelitian ini antara lain:

a. Terdapat banyak alat ukur untuk menilai kinerja Rumah Sakit dengan pendekatan Balanced Scorecard (BSC). Namun karakter Rumah Sakit yang lebih memuat unsur sosial daripada unsur komersialnya, maka rumusan minimal penilaian kinerja Rumah Sakit yaitu: a) Perspektif Keuangan minimal menilai tingkat ekonomis, efisiensi, tingkat eketifitas dan tingkat lancar dari keuangan Rumah Sakit; b) Perspektif Pasien lebih pas dinilai dengan cara melihat tingkat kepuasan pasien terhadap pelayanan Rumah Sakit; c) Perspektif Bisnis Internal lebih pas dinilai dengan cara melihat mutu layanan Rumah Sakit dari sisi ALOS, BOR, TOI, BTO, GDR dan NDR Rumah Sakit; d) Perspektif Pertumbuhan dan Pembelajaran dapat dilihat dengan cara menilai tingkat kepuasan karyawan, tingkat retensi dan tingkat motivasi yang dimiliki oleh karyawan Rumah Sakit.

b. Kriteri pemberian skor untuk masing-masing perspektif penilaian kinerja Rumah Sakit dengan pendekatan BSC bervariasi yang dapat didasarkan pada aturan Menteri Kesehatan, konsep teori dari komponen yang dinilai serta dapat juga menggunakan target capaian dari Rumah Sakit. 
Dengan alasan semua perspektif sama pentingnya, maka dalam penelitian ini merumuskan bobot 4 perspektif sama-sama $25 \%$. Adapun pemberian skor disesuaikan dengan kriteria penilaian yang ada.

Saran untuk penelitian selanjutnya, penggunaan sampel yang digunakan dalam penelitian ini dirasakan masih terbatas pada hasil yang diperoleh dari browsing di Internet, sehingga sangat dimungkinkan masih terdapat banyak sampel yang tidak terjangkau terutama hasil penilaian kinerja Rumah Sakit yang tidak dipublikasikan. Oleh karena itu, hasil penelitian ini belum mampu mengenarilisasi keadaan semua Rumah Sakit yang ada di Indonesia. Dengan demikian saran penelitian selanjutnya, agar mampu menggali hasil penilaian kinerja Rumah Sakit dengan pendekatan BSC lebih banyak lagi terutama dengan cara menelusuri hasil penilaian yang belum atau tidak dipublikasin.

\section{DAFTAR PUSTAKA}

Ariantari, Luh Putu Diah ; Suhaedi, Wirawan ; Isnawati. 2019. Analisis Kinerja Rumah Sakit dengan Pendekatan Balanced Scorecard. Skripsi. Fakultas Ekonomi dan Bisnis. Universitas Mataram.

Aurora, Novella; Raharja. 2010. Penerapan Balanced Scorecard Sebagai Tolok Ukur Pengukuran Kinerja (Studi Kasus Pada RSUD Tugurejo Semarang). Skripsi. Fakultas Ekonomi. Universitas Diponegoro Semarang.

Fahmi, Irham. 2013. Manajemen Kinerja. Bandung : Alfabeta.

Garrison, Ray H. dan Eric W. Noreen. 2000. Akuntansi Manajerial. Jakarta: Salemba Empat.

Halim, Abdul, Achmad Tjahjono, dan Muh. Fakhri Husein. 2000. Sistem Pengendalian Manajemen. Yogyakarta: UPP AMP YKPN. 
Effendy, Hilendria \& Isnawati: Balanced Scrocard (BSC)...

Keputusan Menteri Kesehatan Republik Indonesia Nomor 1981/Menkes/SK/XII/2010 tentang Pedoman Akuntansi Badan Layanan Umum (BLU) Rumah Sakit.

Kothari, C.R. (2004). Research Methodology Methods \& Techniques. New Delhi: New Age International (P) Ltd.

Lestari, Sri; . 2016. Pengukuran Kinerja Dengan Pendekatan Balanced Scorecard pada Rumah Sakit PKU Muhammadiyah Gombong Tahun 2013 dan 2014. Skripsi. Fakultas Ekonomi. Universitas Negeri Yogyakarta.

Mardiasmo. 2002. Akuntansi Sektor Publik. Andi, Yogyakarta.

Nuraeni ; Hilendria, Baiq Anggun ; Isnawati. 2019. Pengukuran Kinerja Strategik: RSUD Patut Patuh Patju Kabupaten Lombok Barat. Skripsi. Fakultas Ekonomi dan Bisnis Universitas Mataram.

Peraturan Menteri Kesehatan Republik Indonesia Nomor 1171/Menkes/PER/VI/2011 tentang Sistem Informasi Rumah Sakit.

Rikamsari, Yopi ; Satibi ; Andayani Tri Murti . 2014. Pengaruh Kinerja Instalasi Farmasi Rumah Sakit X Dengan Pendekatan Balanced Scorecard. Jurnal Manajemen dan pelayanan Farmasi, Volume 4 Nomor 2-4 Juni. Yogyakarta.

Rudianto. 2013. Akuntansi Manajemen. Jakarta : Erlangga.

Sibarani, Antoni; Zahara, Nani Halima; . 2012. Implementasi Balanced Scorecard Sebagai Alat Pengukur Kinerja Pada Rumah Sakit Bhayangkara Polda Bengkulu. Ekonomi Review. Fakultas Ekonomi dan Bisnis Dehasen Bengkulu.

Ulum . Ihyaul 2009. Intellecual Capital Konsep dan Kajian Empiris. Graha Ilmu, Yogyakarta.

Yuwono, Sony. 2002. Petunjuk Praktik PenyusunanBalaned Scoredcard Menuju Organisasi yang Berfokus pada Strategi. PT. Gramedia Pustaka Utama, Jakarta. 